\title{
WADAH KOMUNITAS DAN REKREASI DI KELURAHAN GUNTUR, JAKARTA SELATAN
}

\author{
Mega Dwi Kusumawati ${ }^{1)}$, Diah Anggraini ${ }^{2)}$ \\ 1) Program Studi S1 Arsitektur, Fakultas Teknik, Universitas Tarumanagara, mega.dkw@gmail.com \\ 2) Program Studi S1 Arsitektur, Fakultas Teknik, Universitas Tarumanagara, diah_ismono@yahoo.com
}

\begin{abstract}
Abstrak
Manusia adalah makhluk sosial yang memerlukan tempat untuk berkumpul, berkomunikasi, berinteraksi, bersosialisasi, dan beraktualisasi baik dengan sesama maupun dengan lingkungannya. Dalam menjalankan aktivitasnya selain first place (tempat tinggal/rumah) dan second place (tempat kerja/sekolah) diperlukan suatu setting fisik berupa ruang publik yang dapat menunjang kebutuhan sosial mereka. Ray Oldenberg (1997) mendefinisikan ruang pubik sebagai third place (ruang ketiga) yang berfungsi sebagai tempat khusus di luar tempat tinggal dan tempat bekerja. Kota harus dapat menyediakan ruang publik seperti third place yang bisa diakses oleh masyarakatnya tanpa memandang status sosial, budaya, ataupun tingkat ekonominya. Adanya stratifikasi atau tingkatan sosial yang tersebar di tengah masyarakat, seringkali menghambat interaksi dan komunikasi antar individu satu dengan individu lainnya. Oleh karena itu, kajian ini bertujuan untuk menghasilkan konsep perancangan sebuah third place yang dapat menjadi wadah interaksi, rekreasi, dan pengembangan potensi bagi berbagai lapisan masyarakat, khususnya komunitas/warga penghuni Kelurahan Guntur dengan orang-orang yang setiap harinya melakukan aktivitas di kawasan tersebut (second place) sehingga pada akhirnya dapat berkolaborasi dan memajukan perekonomian masyarakat sekitar. Metode perancangan third place ini menggunakan pendekatan teori Transprogramming dari Bernard Tchumi. Bangunan dirancang dengan menggabungkan dua program utama yang memiliki sifat ruang bertolak belakang: zona kegiatan komunitas dan zona rekreasi. Hasil kajian ini berupa konsep perancangan third place di Kelurahan Guntur, Jakarta Selatan.
\end{abstract}

\section{Kata kunci: komunitas; rekreasi; tempat ketiga}

\begin{abstract}
Human is social creatures who need a place to gather, communicate, interact, socialize, and act both with others and with their environment. In carrying out its activities besides the first place (residence/house) and second place (office/school) a physical setting is required in the form of public space that can support these social needs. Ray Oldenberg defines public space as a third place that functions as a special place outside the residence and office. Cities must be able to provide public space that can be accessed by their people regardless of their social, culture or economic level. The existence of stratification or social levels that are spread in the middle of society often hampering interaction and communication between one individu and the other. Therefore this study aims to produce a design concept, a third place that can be a place of interaction, recreation, and potential development for various layers of society, especially for the community/residents in Guntur District and people who every day carry out activities in the area (second place) so that in the and it can collaborate and advance the community's economy. Using the Transprogramming design method. The building is designed by combining two main programs that have the opposite spatial nature: community activity zone and recreation zone. The Result of the study was a third place design concept in Guntur District, South Jakarta.
\end{abstract}

Keywords: community; recreation; third place 


\section{PENDAHULUAN}

Jakarta merupakan kota dengan tingkat kompleksitas yang tinggi. Seperti masyarakat kota pada umumnya, penduduk kota Jakarta sangatlah beraneka ragam, hal ini dikarenakan anggota-anggotanya terdiri dari latar belakang yang berbeda baik itu dari segi pendidikan, pekerjaan, budaya, dan lain-lain. Perbedaan tersebut kemudian melahirkan lapisan-lapisan atau strata tertentu dalam masyarakat. Pada kehidupan sosial perbedaan strata atau lapisan dalam masyarakat ini disebut juga sebagai stratifikasi sosial.

Manusia adalah makhluk sosial yang memerlukan tempat untuk berkumpul, berkomunikasi, berinteraksi, bersosialisai, dan beraktualisasi diri, baik dengan sesama maupun dengan lingkungannya. Untuk mewujudkan hal itu, mereka membentuk kelompok atau komunitas yang merupakan perkumpulan dari individu yang mempunyai visi, misi, dan tujuan yang sama. Dalam menjalankan aktivitasnya, diperlukan suatu setting fisik berupa ruang publik yang dapat menunjang kebutuhan sosial mereka. Ray Oldenberg (1997) mendefinisikan ruang publik sebagai third place (ruang ketiga) yang berfungsi sebagai tempat khusus di luar first place (tempat tinggal/rumah) dan second place (kantor/sekolah), dimana individu-individu tersebut dapat bertemu, bersosialisai, dan mengaktulaisasi diri mereka tanpa dibatasi oleh hirarki jabatan, status maupun perbedaan sosial dan ekonomi.

Kota harus dapat menyediakan ruang publik yang bersifat terbuka dan dapat diakses oleh masyarakatnya tanpa memandang status sosial, budaya ataupun tingkat ekonominya. Untuk menunjang aktivitasnya, komunitas dan pengguna ruang publik perlu diwadahi berbagai fasilitas yang dapat digunakan bersama. Kajian ini bertujuan untuk menghasilkan konsep perancangan third place yakni berupa Wadah Komunitas dan Rekreasi, yang diharapkan dapat membuat segenap warga, baik penghuni maupun orang-orang yang bekerja/beraktivitas di Kelurahan Guntur, Jakarta Selatan yang datang dari berbagai lapisan masyarakat dapat berinteraksi dan berkolaborasi bersama untuk meningkatkan perekonomian masyarakat sekitar ataupun sekedar menghibur diri dari aktivitas rutinitas sehari-hari mereka.

\section{KAJIAN LITERATUR}

Menurut Wenger (2002) dalam kajianpustaska.com (2019), komunitas adalah sebuah kelompok sosial dari beberapa organisme yang berbagi lingkungan, umumnya memiliki ketertarikan dan habitat yang sama. Dalam komunitas manusia, individu-individu di dalamnya dapat memiliki maksud, kepercayaan, sumber daya, preferensi, kebutuhan, resiko, dan sejumlah kondisi lain yang serupa. Delobelle (2008) dalam kajianpustaka.com (2019) menyatakan bahwa terdapat empat faktor yang melatarbelakangi pembentukan komunitas, yaitu pertaman komunikasi dan keinginan berbagi (sharing), yang mana para anggota saling menolong satu sama lain, kedua tempat yang disepakati bersama untuk bertemu, ketiga adanya ritual dan kebiasaan, sehingga orang-orang datang secara teratur dan periodik, dan terakhir Influencer, yakni merintis sesuatu hal dan para anggota selanjutnya ikut terlibat.

Krippendorf (1994) dalam tribunwisata.com (2017) mendefinisikan rekreasi sebagai kegiatan yang dibutuhkan manusia dengan melakukan perjalan ke suatu tempat. Rekreasi sebagai kegiatan untuk mengisi waktu luang untuk tujuan tertentu, di antaranya penyegaran sikap dan mental, kepuasan, serta kesenangan yang bisa memulihkan kekuatan fisik maupun mental. Sedangkan Mary Helen dalam tribunwisata.com (2017) mendefinisikan rekreasi sebagai peristiwa emosi untuk melupakan aktivitas sehari-hari yang memiliki fungsi agar orang mejadi senang, sehingga fisik dan mental kembali dengan baik.

Berdasarkan definisi di atas maka Wadah Komunitas dan Rekreasi yang akan dirancang dapat diartikan sebagai suatu tempat berkumpul dan mengisi waktu luang individu-individu yang memilki tujuan/kebutuhan/preferensi/sejumlah kondisi lain yang serupa dimana interaksi atau komunikasi menjadi kegiatan utama, guna melupakan sejenak aktivitas sehari-hari mereka.

Dalam buku The Great Good Place, Ray Oldenburg (1997) menyatakan bahwa third place 
memiliki fungsi paling utama yaitu menyatukan komunitas di sebuah lingkungan (neighborhood). la mendefinisikan third place sebagai ruang publik yang berfungsi sebagai tempat khusus di luar first place (tempat tinggal/rumah) dan second place (kantor/sekolah), dimana individu-individu tersebut dapat bertemu, bersosialisai, dan mengaktulaisasi diri mereka tanpa dibatasi oleh hirarki jabatan, status maupun perbedaan sosial dan ekonomi. Beberapa karakteristik menurut Oldenburg, yakni:

a. Neutral, semua orang merasa nyaman karena hubungan yang dapat terjalin lebih intim apabila sudah nyaman.

b. Leveler, dapat diakses oleh seluruh lapisan masyarakat atau masyarakat umum, tidak ada kriteria formal.

c. Conversation, yaitu perbincangan (komunikasi) merupakan aktivitas utama. Dapat menggunakan media lain sebagai katalis untuk orang berinteraksi.

d. Accessibility and Accommodation, akses mudah untuk dicapai atau dikunjungi, jam operasional pada siang dan malam hari (24 jam).

e. Regulars, adanya pengunjung tetap. Kunjungan yang sering dan tetap dapat mempermudah orang-orang untuk mengenal dan berkomunikasi (berinteraksi).

f. A Low Profile, bersifat sederhana, lebih fokus pada masyarakat komunitas sekitar.

g. Playful Mood, suasana menyenangkan, menarik orang-orang yang melewatinya untuk singgah atau mengunjungi third place.

h. A Home Away From Home, berbeda dari rumah, thrid place menyediakan lebih banyak kegiatan dengan aturan publiknya yang bersifat normatif dan fleksibel.

Berdasarkan definisi third place di atas, kajian ini akan menggunakan konsep third place menurut Oldenburg sebagai acuan konsep perancangan yang ideal untuk merancang Wadah Komunitas dan Rekreasi di Kelurahan Guntur, Jakarta Selatan.

\section{METODE}

Metode yang digunakan dalam merancang proyek ini diawali dengan proses deduktif melalui kajian teoritis untuk memperoleh pemahaman terkait third place dan teori-teori yang mendukung, lalu dilanjutkan dengan menentukan lokasi perancangan, menganalisis lokasi tapak dan lingkungan sekitar tapak untuk mengetahui potensi dan menetapkan rumusan permasalahan yang pada akhirnya digunakan untuk menentukan program aktivitas untuk sebuah third place dalam bentuk Wadah Komunitas dan Rekreasi di Kelurahan Guntur, Jakarta Selatan.

Metode perancangan yang digunakan yaitu mengacu pada metode Transprogramming yang terinspirasi dari ide konsep perancangan milik Bernard Tchumi. E. Magee dalam Firdausi, F.S. (2017) menyatakan bahwa Transprogramming merupakan istilah yang diciptakan Bernard Tschumi sebagai salah satu dari tiga opsi yang ia formulasikan untuk mengubah cara pandang kita dalam melihat fungsi dan ruang. Transprogramming sendiri melibatkan kombinasi dari beberapa program yang berbeda dalam gedung yang sama terlepas dari tata ruang dan ketidaksesuaian antara kedua program ini, dan program ini disatukan dalam fungsi objek yang sama. Oleh karena itu objek tersebut berasal dari berbagai konfigurasi yang bersimpangan dimana antar program saling melekat.

Pada perancangan Wadah Komunitas dan Rekreasi di Kelurahan Guntur, Jakarta Selatan menggabungkan dua program utama yaitu program untuk komunitas seperti marker space, start-up office, dan co-working yang bersifat privat dan program rekreasi seperti area asah otak, temporary exhibition, creative space, amphitheater, area bermain sepeda, dan area bermain burung yang bersifat publik yang mana program ini saling bertolak belakang sehingga dibuatlah ruang komunal dan roof garden sebagai ruang transisi yang berfungsi untuk mengikat dua ruang yang berbeda dalam satu bangunan. 


\section{DISKUSI DAN HASIL}

\section{Tinjauan Lokasi}

Proyek Wadah Komunitas dan Rekreasi di Kelurahan Guntur, Jakarata Selatan terletak di Jalan Halimun Raya, Kelurahan Guntur, Kecamatan Setiabudi, Jakarta Selatan. Sisi kanan (sisi tenggara) tapak dibatasi oleh Sekolah TKK-SDK Penabur 9 Halimun, sisi belakang (sisi barat daya) dibatasi oleh Gereja HKBP Menteng Lama, sisi kiri (sisi barat laut) dibatasi oleh Gang Gembira, dan sisi depan (sisi timur laut) dibatasi oleh Jalan Halimun. Lokasi berada di zona perkantoran dan pedagangan (warna ungu) dengan luas area seluas $4000 \mathrm{~m}^{2}$ (dapat dilihat pada Gambar 1).

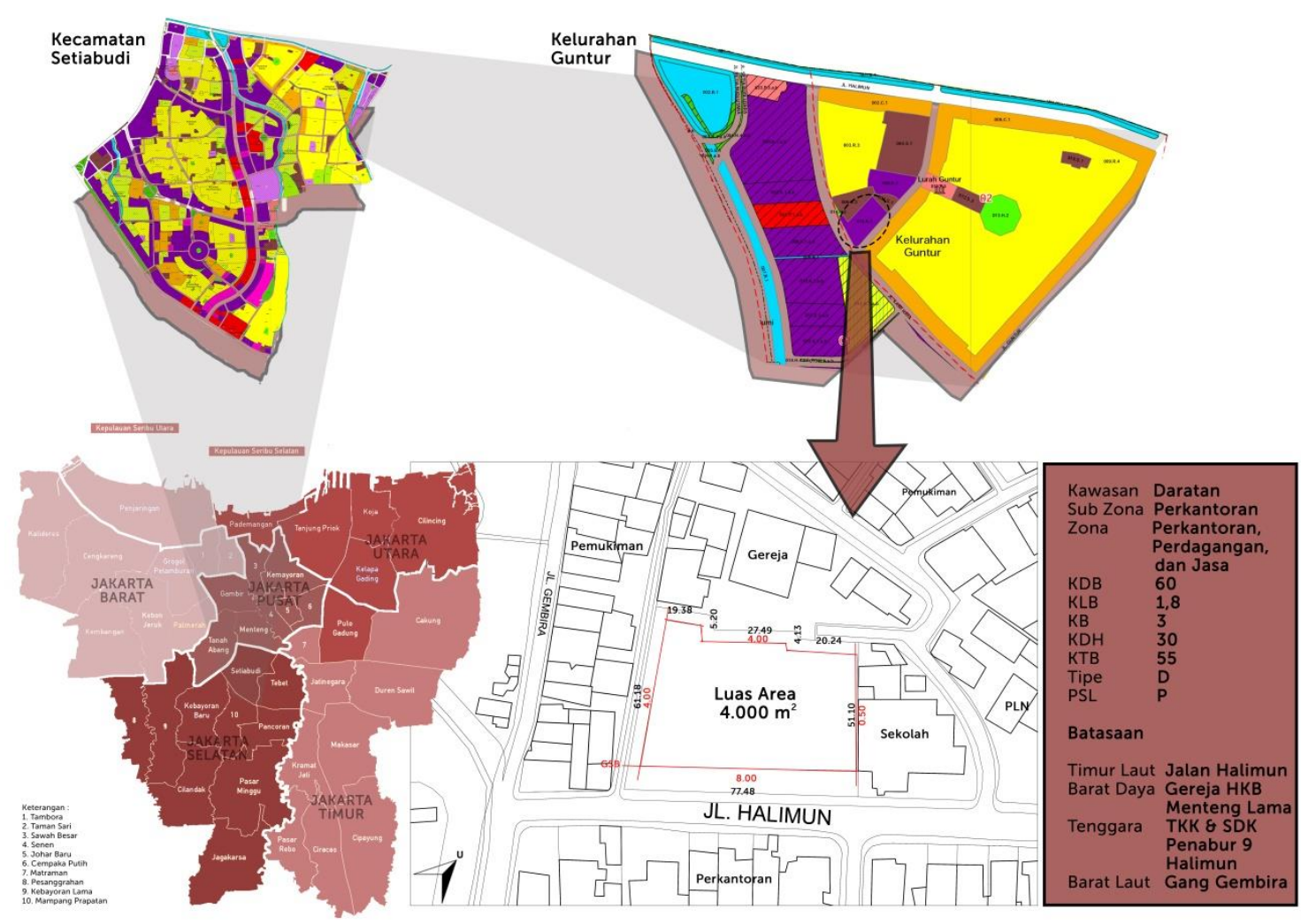

Gambar 1. Profil Tapak

Sumber : Penulis, 2019

Lokasi depan tapak berhadapan langsung dengan perkantoran, di belakangnya terdapat perumahan yang mana masyarakatnya memiliki penghasilan ekonomi menengah-menegah atas, sedangkan wilayah belakang tapak merupakan area perumahan yang mana masyarakatnya memilki penghasilah ekonomi menengah-menengah bawah (dapat dilihat pada Gambar2). Proyek berada pada jalan utama yang dilalui oleh kendaraan umum seperti bajaj, mikrolet, dan Metro-Trans. Tidak hanya itu, lokasi proyek juga merupakan titik pemberhentian Metro-Trans yang melayani Rute 6E (Kota Kasablanka-Halimun), sehingga tapak ini berada di lokasi yang strategis dan mudah diakses dengan transportasi umum. Hal ini sesuai dengan konsep third place yaitu Accessibility and Accommodation. 



Gereja HKBP

TKK dan SDK Penabur 9 Halimun
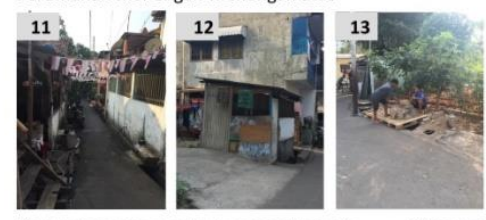

Situasi perkantoran depan tapak
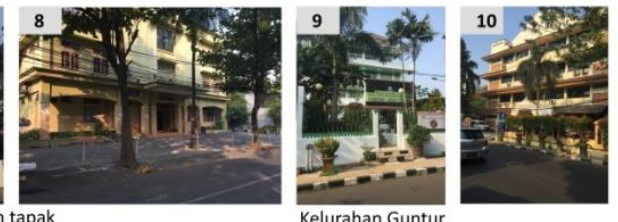

Perumahan menengah-menengah bawah

Jalan yang $d$


Gambar 2. Lokasi Tapak

Sumber: Penulis,2019

Pada Gambar 3 dapat dilihat bahwa lokasi perancangan berada dekat dengan first place (tempat tinggal) dan second place (tempat bekerja/sekolah). Hal ini menjadikan lokasi perancangan berpotensi sebagai tempat untuk pelarian sejenak indivduindividu dari aktivitas sehari-hari mereka sekaligus membuka peluang bagi individu-individu yang ingin mengaktualisasi diri dan bersosialisasi. Lokasi berada di tengah perumahan masyarakat penduduk dengan pendapatan ekonomi yang berbeda. Hal ini menjadikan lokasi perancangan berpotensi sebagai tempat yang neutral (sesuai dengan konsep third place) untuk mempertemukan penghuni yang berada di perumahan menengah-menegah bawah dengan penghuni perumahan menengah-menengah atas, sehingga stratifikasi sosial yang kerap menjadi penghalang antar individu untuk berinteraksi pun semakin menipis. Adanya program thrift shop (tempat jual-beli barang tidak terpakai) dalam banguanan dapat dijadikan peluang bisnis bagi masyarakat sekitar selain merupakan awal mula interaksi baru.

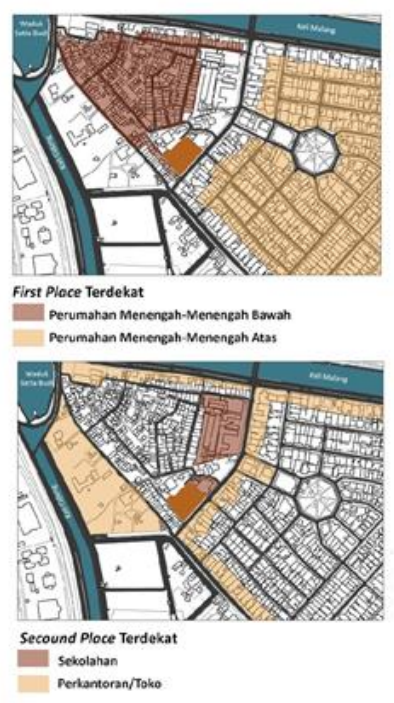

Gambar 3. First Place dan Second Place Terdekat. Sumber: Penulis, 2019

\section{Kebutuhan Masyarakat Sekitar}

Aktivitas yang ada di dalam proyek ini dibagi menjadi 3, yaitu aktivitas utama, penunjang, dan servis. Aktivitas utama dalam proyek ini dibagi menjadi dua program utama yang didapatkan dari hasil analisis kebutuhan masyarakat sekitar tapak (dapat dilihat pada Gambar 4) yaitu program untuk komunitas dan program rekreasi. 


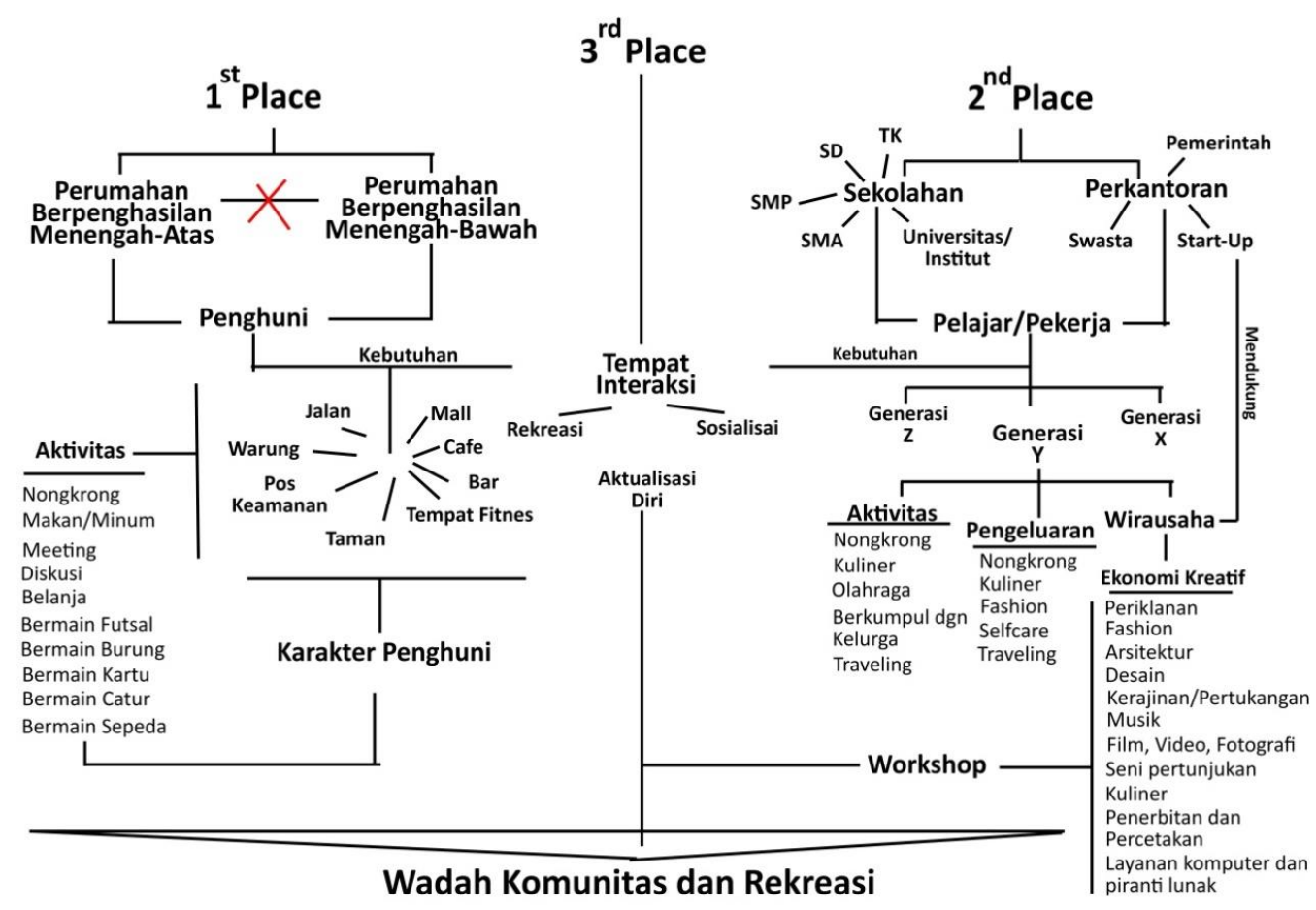

\section{$3^{\text {rd }}$ Place}

Gambar 4. Diagran Kebutuhan

Sumber : Penulis, 2019

Program untuk komunitas dapat digunakan pengunjung untuk mengeksplorasi dan mengaktualisasi diri mereka, mengingat lokasi proyek yang berada dekat dengan wilayah perkantoran dan hunian. Pengunjung dapat menggunakan wadah untuk komunitas tersebut sebagai tempat belajar hal baru ataupun melakukan hobinya. Dalam proyek terdapat makerspace yang memfasilitasi pengunjung untuk berkarya baik dalam bidang fashion, seni digital, ataupun perkayuan. Selain itu juga terdapat co-working space dan start-up office yang dapat digunakan pengunjung yang ingin memulai karirnya dalam berwirausaha. Tidak hanya itu, adanya ruang temporary exhibition dalam proyek dapat dimanfaatkan pengunjung sebagai ajang mempromosikan diri (melalui hasil karya seni) selain sebagai tempat memamerkan dan mengapresiasi hasil karya seni mereka.

Program rekreasi dapat digunakan pengunjung untuk mereleksasikan dan menghibur diri mereka dari penatnya kegiatan sehari-hari. Pada proyek disediakan area bermain futsal, area bermain sepeda, area bermain burung, area asah otak, creative space, dan amphitheater yang dapat digunakan pengunjung untuk menghibur diri dan bersosialisasi.

Fasilitas yang akan menunjang proses interaksi dalam proyek ini terdiri dari beberapa program penunjang yakni food court, café, thrift shop, roof garden, dan ruang komunal. Program penunjang ini dapat memberikan kenyamanan lebih untuk pengunjung dalam berinteraksi baik itu dengan orang baru maupun dengan rekan sepermainan.

Aktivitas servis disediakan untuk pengelola bangunan guna sebagai tempat untuk melakukan aktivitas pemeliharaan dan perawatan bangunan agar bangunan senantiasa dapat melayani kegitan sosialisasi pengunjung secara optimal.

\section{Program Ruang}

Berdasarkan kebutuhan masyarakt sekitar lokasi proyek maka Wadah Komunitas dan Rekreasi di Keluraha Guntur, Jakarta Selatan ini menghasilkan program ruang sebagai berikut : 




\section{Program Ruang}

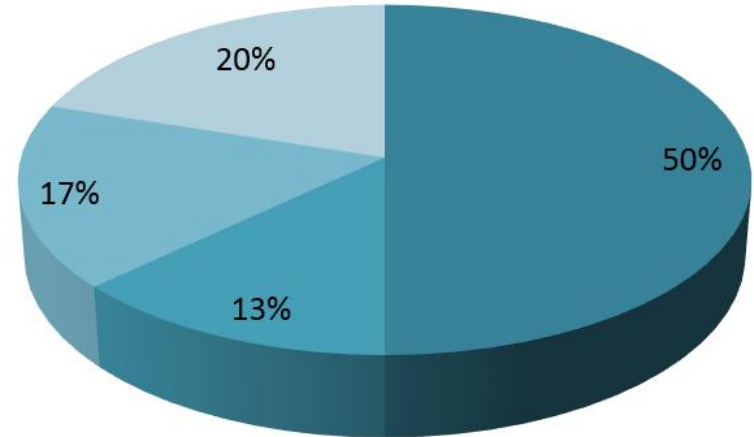

$$
\begin{aligned}
& \text { - Program Utama } \\
& \text { Program Tambahan } \\
& \text { Program Pendukung (Service) } \\
& \text { Sirkulasi }
\end{aligned}
$$

Gambar 5. Program Ruang

Sumber: Penulis, 2019

Pada Gambar 5 dapat dilihat bahwa program dalam bangunan Wadah Komunitas dan Rekreasi di Guntur, Jakarta Selatan ini dikategorikan menjadi 3 yaitu program utama, program tambahan, dan program pendukung (service) dengan rincian $50 \%$ untuk kebutuhan program utama, $18 \%$ untuk program tambahan, $12 \%$ untuk service dan $20 \%$ untuk sirkulasi.

Terdapat dua program utama yaitu program untuk komunitas dan program rekreasi. Program rekreasi yang terdiri dari creative space, amphitheater, temporary exhibition, perpustakaan, area sepeda, area burung dara, lapangan futsal, area asah otak, dan thrift shop (tempat jual-beli barang tidak terpakai). Program ini masuk dalam zona publik yang dapat diakses oleh siapapun, sedangkan program untuk komunitas yang terdiri dari co-working, maker space (fashion), maker space (woodworkig), maker space (laboratorium digital), dan startup office masuk ke dalam zona privat. Pada program untuk komunitas ini sifat ruangnya lebih privat karena hanya anggota-anggota tetap atau anggota yang telah terdaftar saja yang dapat mengakses ruang secara keseluruhan.

Proyek Wadah Komunitas dan Rekreasi di Kelurahan Guntur, Jakarta Selatan ini memiiki area bangunan seluas $6.134,2 \mathrm{~m}^{2}$ dengan rincian luas yaitu lantai satu $1.261,5 \mathrm{~m}^{2}$, lantai dua $771,9 \mathrm{~m}^{2}$, lantai tiga $729,2 \mathrm{~m}^{2}$, lantai basement $868,6 \mathrm{~m}^{2}$, ruang luar $1.484 \mathrm{~m}^{2}$, dan area sirkulasi seluas $1.019 \mathrm{~m}^{2}$.

\section{Konsep Perancangan}

Bangunan dirancang untuk ramah pejalan kaki, jalur kendaraan bermotor (mobil dan motor) hanya dapat melewati sisi depan bangunan dan kemudian dialihkan ke area basement untuk pengunjung yang ingin parkir kendaraan mereka. Kegemaran anak-anak sekitar lokasi proyek dalam bermain sepeda menjadai dasar untuk memasukkan area bermain sepeda dalam bangunan, sehingga dibuatlah jalur sepeda yang hampir dapat mengelilingi bangunan. Permaianan level lantai digunakan untuk menjadi pemisah antara jalur pejalan kaki dan jalur sepeda pada bangunan, hal ini dilakukan untuk menjaga tingkat keamanan dan kenyamanan pengunjung (baik pengunjung yang menggunakan sepeda atau tidak). Walaupun demikian terdapat beberapa titik yang dapat mempertemukan pengunjung bersepeda dan tidak, hal ini dibuat agar baik pengunjung bersepeda dan tidak tetap dapat berinteraksi satu sama lain. 


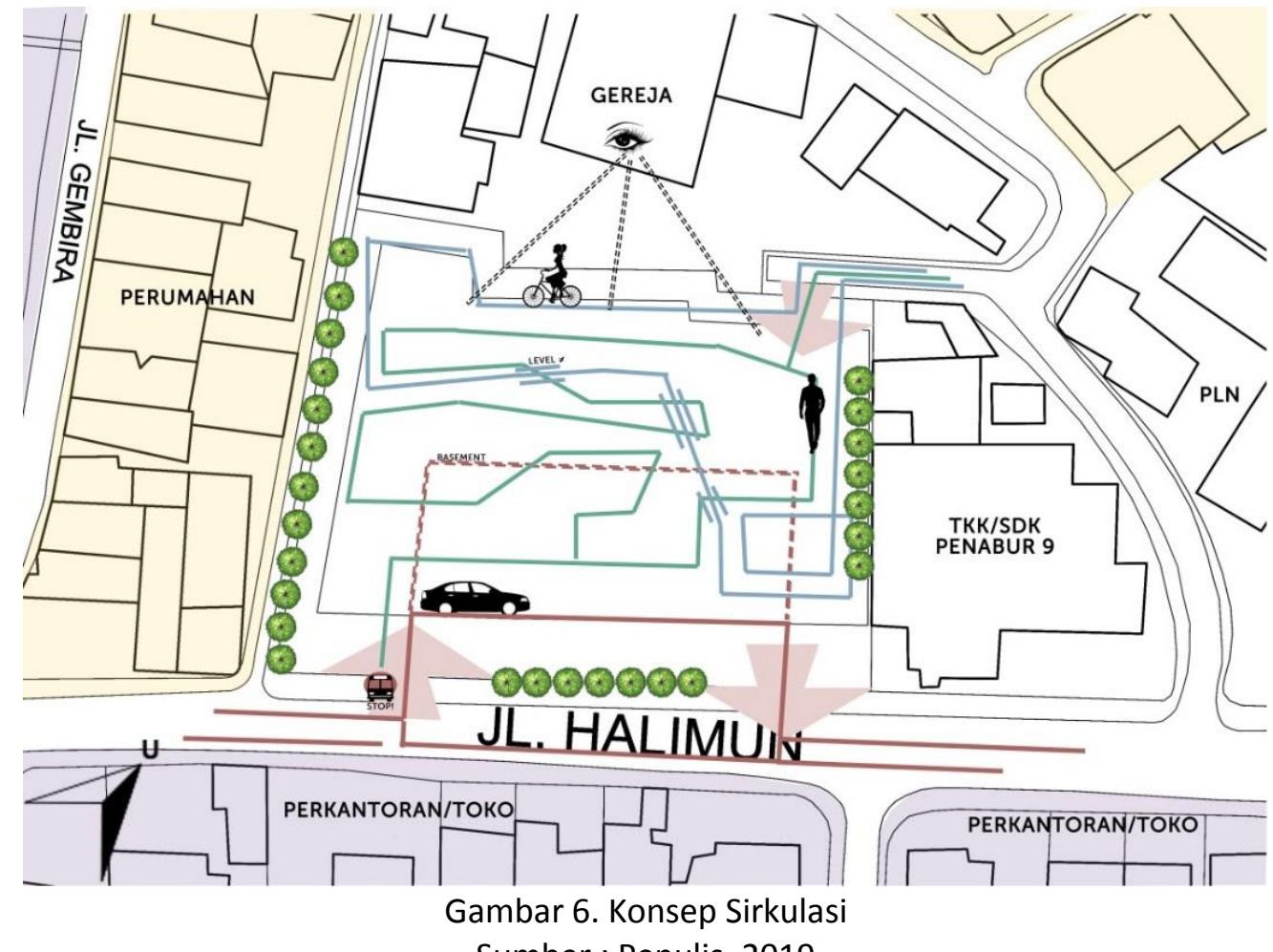

Sumber : Penulis, 2019

Pada Gambar 6 dapat dilihat bahwa terdapat dua akses masuk ke dalam bangunan, akses masuk utama terdapat di sisi depan (sisi timur laut) yang mana berhadapan langsung dengan jalan raya Halimun sehingga memudahkan orang-orang yang berda di sekitar lokasi untuk singgah dan berhenti. Sedangkan akses masuk lainnya terdapat di sisi belakang (sisi barat daya) berdekatan dengan pintu masuk Gereja HKBI Menteng Lama. Wilayah belakang tapak yang dekat dengan perumahan yang mana anak-anak senang bermain sepeda menjadi dasar pertimbangan dibuat akses masuk ini, agar anak-anak dapat mudah mencapai bangunan.

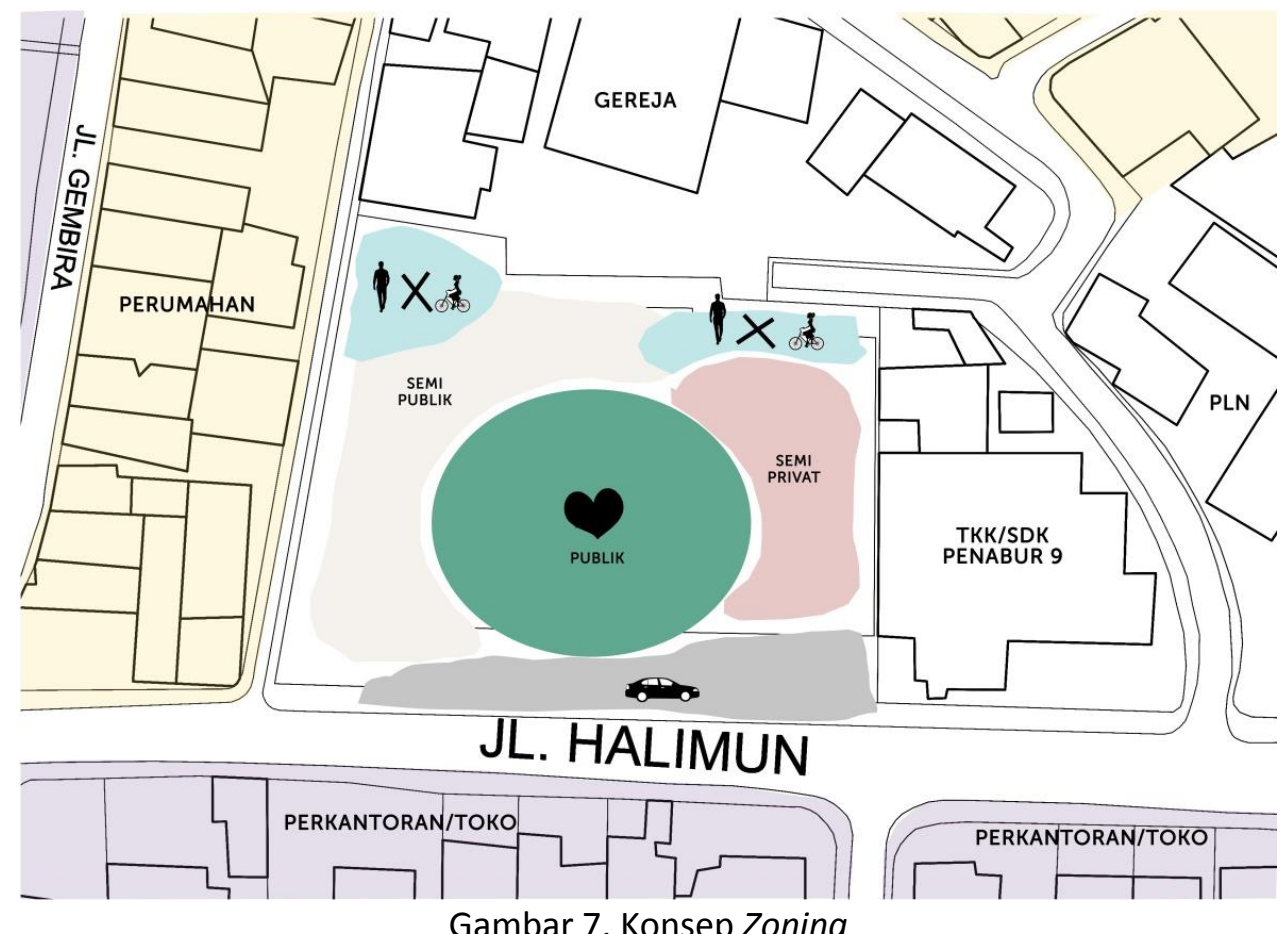

Gambar 7. Konsep Zoning

Sumber : Penulis, 2019 
Sebagai bangunan publik, bangunan dirancang terbuka pada bagian dasar, walaupun demikian tatap terdapat tingkatan sifat karakter ruang didalamnya. Pada Gambar 7 dapat dilihat bahwa terdapat zona semi privat (warna merah) yang mana area ini tetap dapat diakses publik namun memiliki tingkat keamanan yang lebih tinggi. Zona semi privat diletakan dekat dengan sisi sekolah (TK/SD Penabur 9 Halimun) agar kebisingan yang timbul dari aktivitas pengguna dalam bangunan tidak mengganggu aktivitas penghuni bangunan sekolah. Sedangkan pada sisi area yang berhadapan dengan gereja digunakan untuk zona semi publik (warna coklat), memiliki fungsi food court dan café hal ini bertujuan agar dapat menarik pengunjung gerja untuk singgah dan mendatangi bangunan. Pada bagian tengah bangunan diisi oleh zona publik (warna hijau) hal ini bertujuan untuk mengikat program-program yang memiliki sifat privat agar tetap dapat melebur menjadi satu. Zona publik ini merupakan jantung dari bangunan, pusat dari kegiatan interaksi dan komunikasi dalam bangunan.

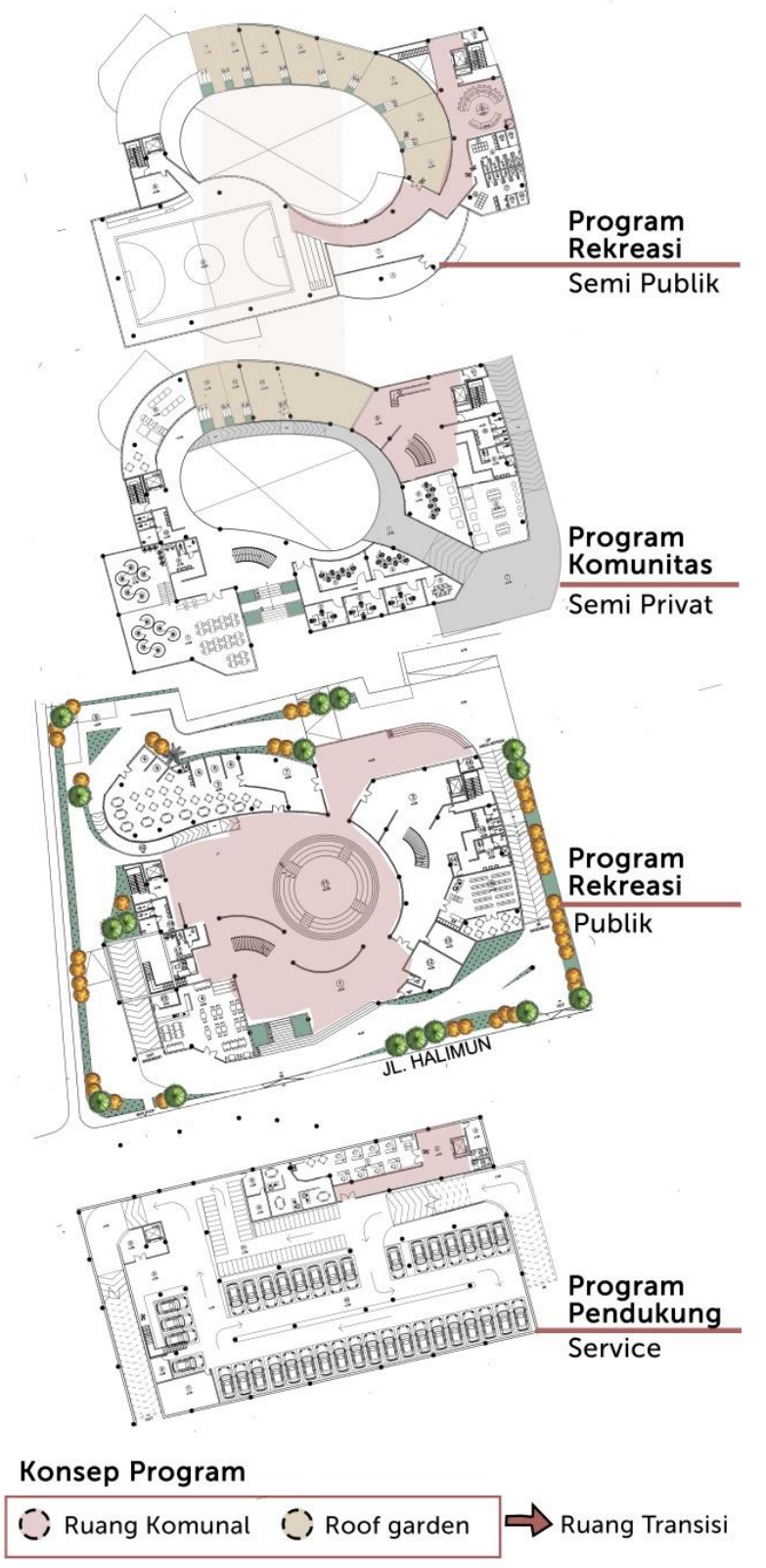

Gambar 8. Konsep Program

Sumber: Penulis, 2019 
Dengan menggunakan metode pendekatan transprogramming rancangan third place ini akan menggabungkan dua program utama yang memiliki sifat ruang yang bertolak belakang. Program untuk komunitas yang bersifat privat di letakkan di tengah bangunan (lantai 2) sedangkan program rekreasi diletakan pada lantai 1 dan 3 dengan mengapit program yang bersifat privat ini bertujuan untuk tetap menciptakan suasana yang menyenangkan (sesuai dengan konsep dari third place) sehingga dalam mengaktualisasi dirinya pengguna bangunan tidak merasakan bahwa ia sedang bekerja melainkan mengerjakan suatu yang mereka sukai dengan suasan yang hangat. Walaupun demikian pengguna bangunan tetap memiliki personal space hal ini karena adanya zona transisi yang berupa ruang komunal dan roof top yang dijadikan sebagai ruang penghubung dan ruang pengikat dalam banguanan (dapat dilihat pada Gambar 8).

\section{Hasil Desain}

Bangunan terdiri dari tiga lantai dan satu basement. Lantai satu dan lantai tiga digunakan untuk aktivitas publik sedangkan lantai 2 digunakan untuk aktivitas privat. Lantai basement digunakan sebagai area servis dan kegiatan pengelola bangunan dalam hal merawat mau pun mengoprasionalkan bangunan (dapat dilihat pada Gambar 9).

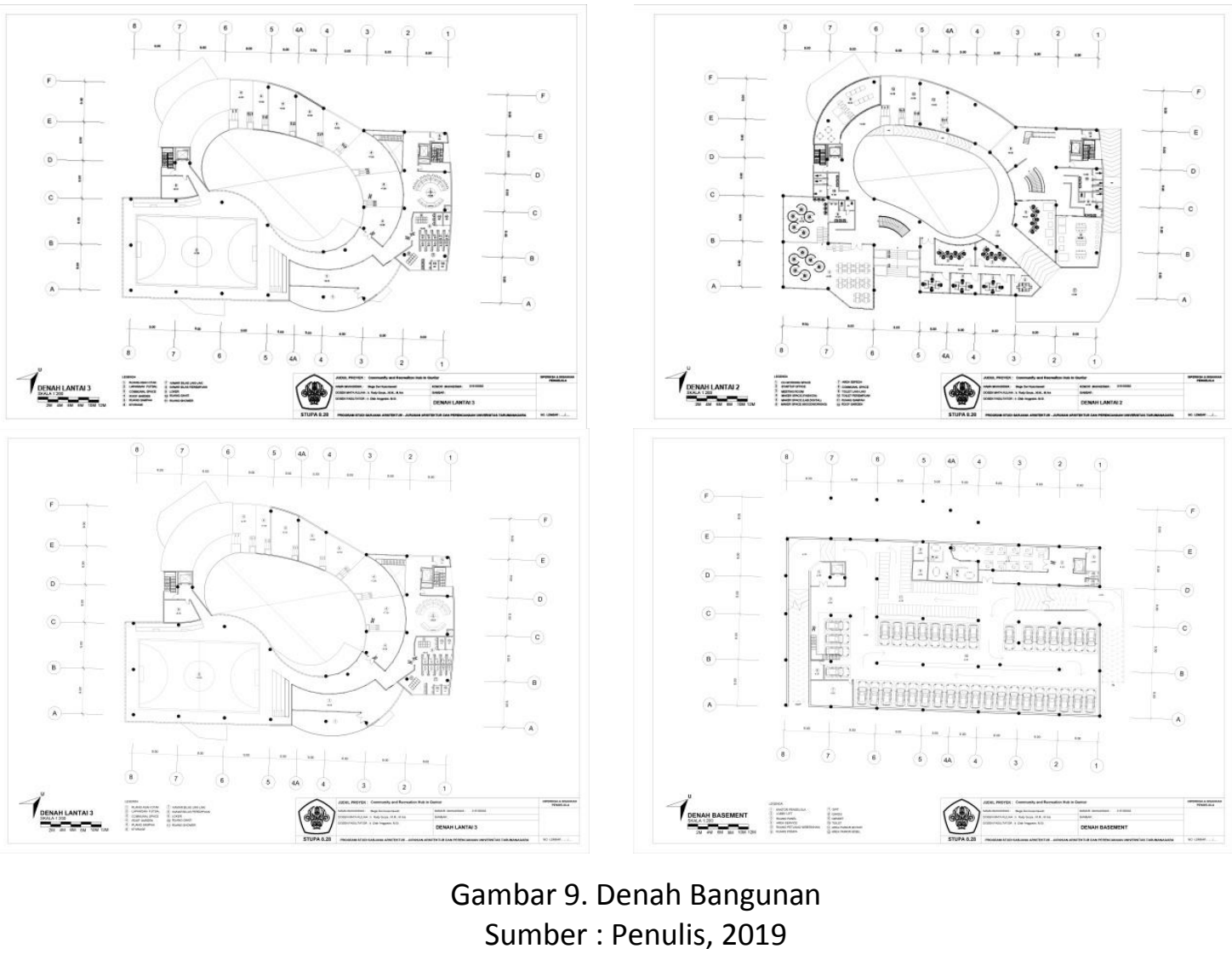

Pada gambar denah bangunan di atas dapat dilihat bahwa pada setiap lantainya terdapat ruang komunal, ruang ini merupakan ruang transisi agar pengunjung yang menjadikan bangunan sebaga tempat berkerja atau pun pengunjung yang menjadikan bangunan sebagai tempat rekreasi/istirahat dapat dengan nyaman melakukan aktivitasnya di sisi lain adanya ruang komunal ini juga sebagai solusi untuk meningkatkan kegiatan interaksi sosial pengunjung bangunan. 

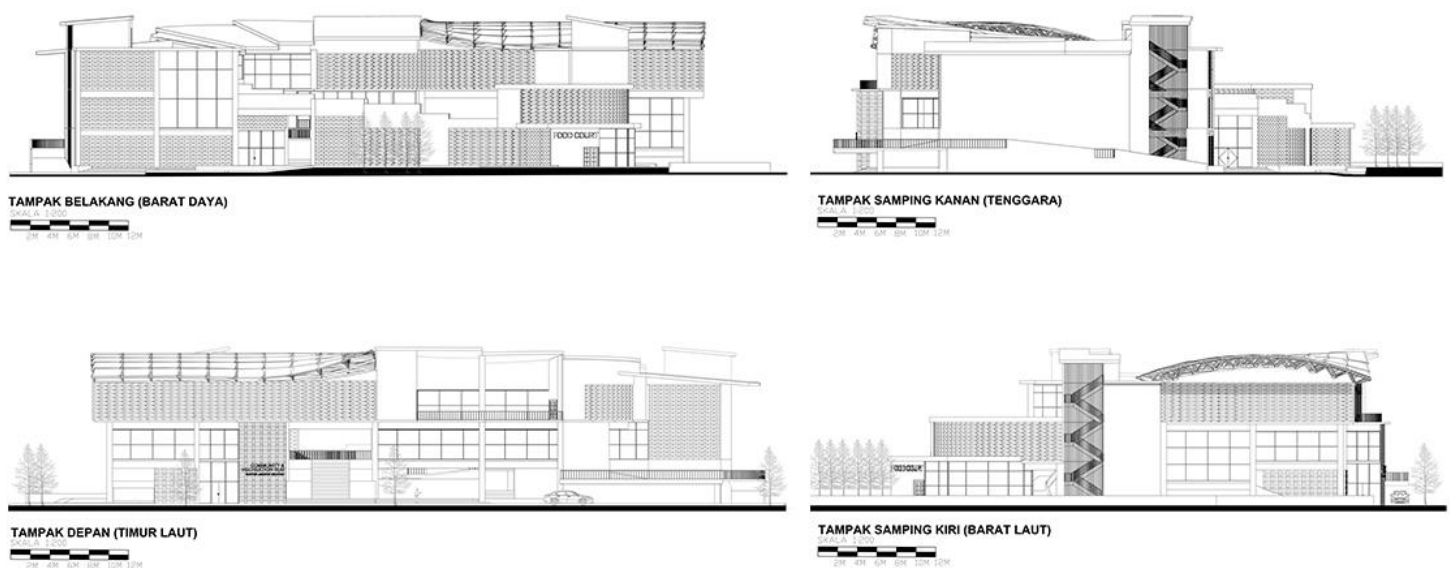

Gambar 10. Tampak Bangunan

Sumber: Penulis, 2019

Pada Gambar 10 memperlihatkan penggunaan material batu bata yang diekspos. Selain menghemat biaya pembangunan penggunaan material batu bata yang diekspos ini memberikan kesan hangat terhadap bangunan sehingga pengguna bangunan pun dapat merasakan kenyamanan seperti berada di rumah mereka. Pada tampak belakang bangunan terlihat roof garden yang bertarap untuk menciptakan kesan yang terbuka, mengingat bagian belakang bangunan berhadapan langsung dengan bangunan sosial, yaitu gereja.

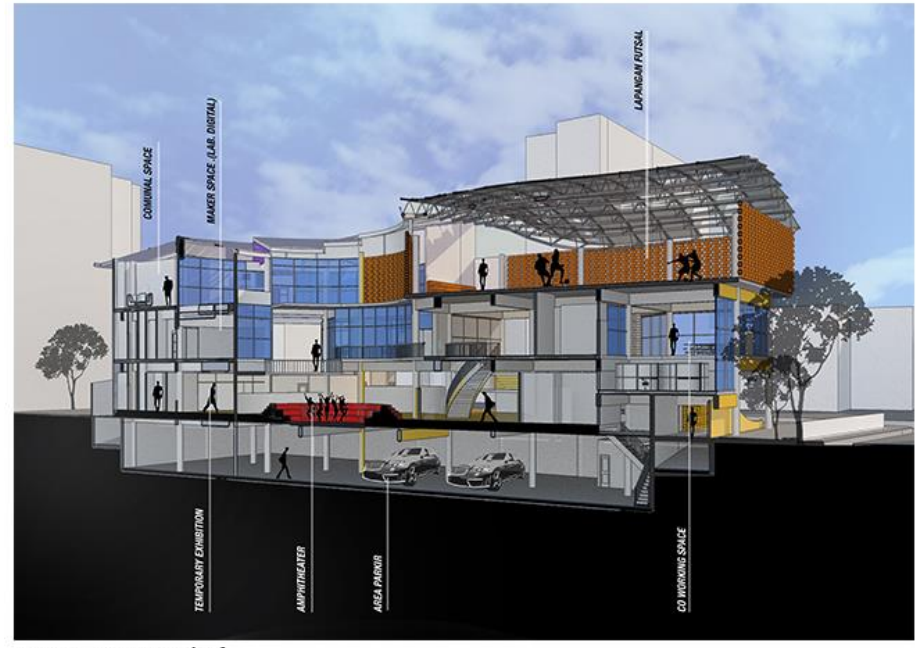

Potongan Perspektif

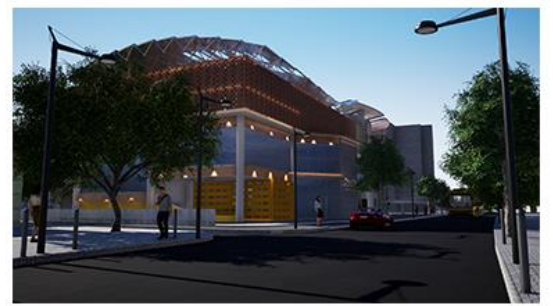

Perspektif Eksterior (Muka Bangunan)



Perspektif Eksterior (Amphitheater)

Gambar 11. Persepektif Bangunan

Sumber: Penulis, 2019

Amphitheater dijadikan sebagai titik kumpul atau interaksi utama pada bangunan, dimana di sana masyarakat dapat mengekspresikan diri mereka sambil berinteraksi dengan orangorang baru, seperti yang terlihat pada Gambar 11. Tidak hanya itu orang-orang yang sedang menikmati waktu luang mereka di roof top pun dapat langsung melihat ke bawah sehingga tingkat interaksi antar pengguna bangunan pun dapat lebih maksimal.

\section{KESIMPULAN DAN SARAN}

\section{Kesimpulan}

Dalam merancang suatu third place dalam hal ini berupa Wadah Komunitas dan Rekreasi di Kelurahan Guntur, Jakarta Selatan perlu diperhatikan agar bangunan harus dapat dijadikan 
sebagai tempat berkumpul dan bersosialisasi seluruh lapisan masyarakat. Oleh karena itu untuk mewadahi kebutuhan individu-individu yang berbeda latar belakangnya digunakan metode pendekatan transprogramming. Untuk tetap menjaga privasi dan personal space yang dimiliki oleh masing-masing individu selain melakukan permainan level pada lantai bangunan juga dibuat ruang transisi yakni berupa ruang komunal dan roof garden sebagai pengikat dua ruang yang memiliki sifat ruang yang berbeda sehingga bangunan pun tetap terlihat terbuka dan fleksibel dan pengguna bangunan tetap dapat dengan nyaman melakukan aktivitas dan berinteraksi di dalamnya.

\section{Saran}

Disarankan adanya penambahan program-program di dalam bangunan Wadah Komunitas dan Rekreasi di Kelurahan Guntur, Jakarta Selatan agar dapat menampung lebih banyak komunitas atau masyarakat sekitar dalam beraktivitas dan berinteraksi sosial. Penambahan program dapat menambah variasi kegiatan dalam bangunan dan dapat meningkatkan daya tarik masyarakat sekitar untuk datang dan berkegiatan dalam Wadah Komunitas dan Rekreasi di Kelurahan Guntur, Jakarta Selatan.

\section{REFERENSI}

Firdausi, F. S. (2017). Pendekatan Transprogramming untuk Mewujudkan Efisiensi Ruang berdasarkan Perubahan Aktivitas dan Waktu. Jurnal Sains dan Seni POMITS Vol.6, No. 2 (2017) 2337-3520 (2301-928X Print)

Kajianpustaka.com.(2019,12 Juni). Pengertian, Unsur dan Bentuk-bentuk Komunitas. Diakses pada 7 Januari 2020, dari https://www.kajianpustaka.com/2019/06/pengertian-unsur-danbentuk-komunitas.html

Oldenburg, R. (1997). The Great Good Place. Da Capo Press:U.S.

Tribunwisata.com.(2017,31 Agustus). 5 Pengertian Rekreasi menurut Para Ahli secara Etimologis \& Manfaatnya. Diakses pada 7 Januari 2020, dari https://www.tribunwisata.com/2017/08/5-pengertian-rekreasi-menurut-para-ahli-secaraetimologis-manfaatnya.html 